\title{
5 \\ Internationalizing the National University
}

The gleaming new campus of New York University Abu Dhabi (NYUAD) is located on Saadiyat Island, a natural island off the coast of Abu Dhabi and a cultural and tourist hub for the emirate. Saadiyat's cultural district will include the Zayed National Museum, the Louvre Abu Dhabi, and the Guggenheim Abu Dhabi. The campus's architecture combines the country's Arab and Islamic heritage with the most up-todate environmental practices; the spacious and green campus includes high-end libraries, facilities, and computer labs. Roughly a decade after its launch, there is no doubt that NYUAD has made an impact: its acceptance rate of 2-4 per cent of applicants makes it as competitive as any American Ivy League university, and it has attracted a diverse faculty of the highest calibre from elite universities around the world.

On the one hand, NYUAD is a clearly Emirati project; it has been funded almost entirely by the Nahyans, the ruling family of Abu Dhabi, which is the largest and wealthiest of the seven emirates in the UAE. Campus construction alone is estimated to have cost a staggering USD 1 billion, and, post-construction, the government of Abu Dhabi continues to provide generous financial aid to qualified students to lure them away from Ivy League universities and other top colleges.

On the other hand, there is very little about NYUAD that speaks to it being a national project. Rather, it feels like a global project that just happens to be located in Abu Dhabi. The sparkling new campus, which integrates cultural and architectural traditions from Abu Dhabi with those of New York City, was designed by Rafael Viñoly Architects, a firm founded by a Uruguayan architect based in New York City. Similarly, its brand is self-consciously "global." NYUAD calls itself "the world's honors college" and seeks to educate "global leaders." Its home university, New York University (NYU), also calls itself "a global university" and insists that NYUAD is not simply a branch of the original campus 
in Lower Manhattan. Instead, along with its other co-equal campus in Shanghai, the three campuses make up what NYU calls a globally networked university.

NYUAD is only one of many symbols of international higher education in the Arab Gulf states. In Doha, Qatar's capital, the Qatar Foundation hand-picked eleven elite schools and invited them to open branches in a large and state-of-the-art campus known as Education City. After more than ten years, at many of the branch campuses a majority of students are Qatari citizens. Meanwhile, Abu Dhabi's larger and more cosmopolitan rival to the north, Dubai, has created a hub for branch campuses, known as Academic Village. Unlike NYUAD and Qatar's Education City, Dubai's Academic Village targets the roughly 90 per cent of Dubai residents who are non-citizens. It hosts dozens of branch campuses of varying levels of quality to educate a large and diverse non-elite for the labour market.

The founding of NYUAD and other branch campuses and educational hubs in the Arab Gulf states is only one of many types of international engagement in the region. Other forms include the establishment of binational universities, such as the German Jordanian University; generous new scholarship programs that fund Arab students to study abroad; North African universities' participation in European research networks; and the recruitment of foreign students to the region. These initiatives are all ways in which the desire to "be international" is altering Arab higher education systems.

This phenomenon of "going global" is known as internationalization, and it is one of the most fundamental shifts in global higher education (Knight, 2008; Wildavsky, 2012). This chapter explores how and why Arab nations engage in higher education internationalization. It argues that the links between internationalization and preparation for a future knowledge economy are tenuous. Rather, at the individual and institutional level, internationalization is a way to signal legitimacy and distinction. Foreign-language degrees and student or scholarly mobility programs are widely celebrated as "opportunities" that confers status on participating individuals. In the aggregate they constitute a class project of the globally oriented upper-middle class by supporting their aspirations for transnational mobility and status.

At the national level Arab governments link internationalization to discourses of modernization, development, and quality. Throughout the region, internationalization is being used to prove state capacity and to project the image of a government that is simultaneously globally engaged and nationally focused. In the Arab Gulf states, ruling families' support for international branch campuses is part of larger state 
development and nation branding projects. Given their expense, however, few countries can afford this model. For middle-income countries in the region, including Egypt, Lebanon, Jordan, Morocco, and Tunisia, internationalization offers a way to signal a high level of quality while also securing external resources.

There is no doubt that these projects have positively affected many students, professors, and researchers. But their benefits are not equally distributed. In the Arab Gulf states there are concerns that the substantial government funding put into niche projects and scholarships comes at the expense of public universities and implies that the latter are less prestigious. Critics rightly maintain that branch campuses benefit very few national citizens, at the possible expense of the majorities in national institutions. Throughout the region, opportunities for international engagement map onto long-standing linguistic, geographic, and class divides that benefit those who already possess significant linguistic, economic, social, and cultural capital.

Fundamentally, internationalization reflects a Western orientation that maps onto patterns of colonial influence and benefits Western institutions and businesses. As currently practised, internationalization reinforces the idea that, by adopting Western models of higher education, Arab states will secure external legitimacy associated with high-quality higher education. In so doing, it reproduces global academic hierarchies.

An alternative vision for internationalization in the region would disrupt the assumed linkages between "international," "Western," and "prestige." This might start by recognizing that the Arab world is already deeply internationalized: its youth are multicultural, multilingual, cosmopolitan, and mobile. International engagements are an opportunity to highlight the region's cultural heritage and to share the region's knowledge with a world that is, at best, ignorant, or worse, overtly biased in its perceptions of the Arab world. A second approach would be to strengthen regional collaboration and internationalization the higher education systems in the region have a lot to offer to those in neighbouring countries, and stronger links between the region's institutions could build opportunities for regional collaboration in tackling similar social issues and promoting knowledge production in Arabic.

\section{The Internationalization Imperative}

International academic mobility in higher education is not new. For centuries the renowned institutions of higher learning in the region, including Qarawiyyin in Fez and Al-Azhar in Cairo, attracted Islamic 
scholars and students from throughout the Middle East, Africa, Europe, and beyond (Farag, 2010). During the colonial era the most promising students travelled to Europe for graduate studies, and after independence international study remained largely dependent on the colonizing power, given the lack of doctorate-granting institutions in the region. This model of international mobility was one of importation, reflecting the power imbalance of the colonial era, yet it also played an important role in developing modern Arab higher education systems.

Over the past two decades, however, greater attention has focused on international engagements in higher education. This internationalization is typically defined as the "integration of international and global dimensions into universities' missions, programs, and operations" (Knight, 2004, p. 11). The "internationalization imperative" affecting higher education around the world is closely linked to knowledge economy discourses, where nations are seen as competing not only for foreign capital but also for labour, characterized as "talent" (Nielsen, 2012). Higher education institutions around the world are being called upon to prepare youth for global labour markets by reforming whom, what, and where they teach. Over the past two decades there has been a veritable revolution in international engagement in higher education, characterized by new actors, models, and types of programming and an increase in the sheer numbers of students and scholars who are studying abroad. In this new global era, a highly internationalized university is now framed as an asset that helps a country be competitive in the global academic and economic marketplace (Wildavsky, 2012).

From this perspective internationalization is both important and desirable. It is framed as one way to improve academic quality, support scientific research, and contribute to mutual understanding, among other positive outcomes. A 2012 report by the OECD claims that integrating internationalization into higher education may "contribute to country-wide growth and innovation" and may "influence key areas of the world and global development" (Hénard, Diamond, \& Roseveare, 2012, p. 11). In fact, indicators of internationalization such as an institution's number of international students are used as proxies for quality and are key measures in some global rankings of university quality.

As such, internationalization is part of the larger package of reforms that both universities and countries are expected to pursue in the name of global economic competitiveness. Typical reforms include recruiting foreign students, reforming curricular content to promote international awareness, and teaching foreign languages. In line with these discourses, national governments throughout the Arab region have embraced internationalization in many forms, from offering scholarship 
programs and recruiting international students to founding branch campuses and binational universities. In the section that follows, I distinguish between "people" mobility, which includes scholarship programs and the recruitment of international students, and "program" or "provider" mobility, which refers to universities and programs moving across borders.

\section{People Mobility}

The movement of students across borders is one of the oldest forms of international engagement in higher education and remains one of the primary ways in which students from the world over learn with and from one another. The phenomenon of sending and receiving "international students" is not new, as Arab countries have long histories of student mobility to and from Europe and the Soviet bloc. In the first half of the nineteenth century Muhammad Ali, the Ottoman governor (Wali, in Arabic) of Egypt, sent students to learn abroad and invited foreign scholars to Egypt, in the name of modernization and development (Farag, 2010). In the post-Second World War era the purposes and discourses associated with international study have mapped onto geopolitical projects. Farag (2010) reminds us that the mobility of students and scholars between Europe and the Arab world is simultaneously "related to European colonialism and to cosmopolitanism" and the complex relationship between the two (p. 285). Meanwhile, Katsakioris (2016) finds that during the Cold War over fifty thousand Arab students studied in the USSR as part of broader Arab-Soviet co-operation programs. In the next section I discuss many of the well-known scholarship programs supporting student mobility.

\section{Bilateral Scholarship Programs}

In the post-colonial era national governments funded a host of bilateral and multilateral scholarly exchange programs in the name of national development, knowledge exchange, and soft power. During the Cold War, scholarship programs were aligned to the geopolitical priorities of the funding nation. Scholarly mobility served as a way to promote the image of the funding nation while also building relationships with future leaders in parts of the world deemed strategic. One of the more prominent programs in the West is the Fulbright Program, which was established in 1946 by J. William Fulbright, a United States senator, as a way to build goodwill and cross-cultural understanding between formerly warring countries and to promote American interests around the 
world (Lebovic, 2013). Similarly, during the Cold War, Arab students also studied throughout the Soviet bloc, as scholarships for Arab students were incorporated into the USSR's broader geopolitical efforts to gain strategic position in the region through bilateral co-operation in military, industrial, and cultural initiatives (Hannova, 2014). Following Arab nations' independence, Moscow offered state-funded scholarships for Arab students to study throughout the USSR. Katsakioris (2016) shows that the number of Arab students studying in the USSR increased each decade, from 2,000-3,000 in the 1960s, to 4,000-5,000 in the early 1970 s, to roughly 10,000 by 1980 , and doubling to 20,000 a year by the late 1980s. The largest numbers of students came from Syria, Yemen, Jordan, and Lebanon, with large numbers also coming from Iraq, Algeria, Egypt, Palestine, Sudan, Morocco, and Tunisia.

One historical example of Soviet-era scholarship programs is Czechoslovakia's Operation 90, which provided scholarships for students from "less-developed" countries, including many Arab nations where the Czech government was promoting a sense of international socialist solidarity. Operation 90 was founded in 1956 and offered roughly ninety scholarships a year, with many students coming from Egypt, Syria, and Lebanon. Hannova (2014) reports that Operation 90 prioritized students from prominent families, who had military or political connections and sympathies for socialism, rather than nationalism. In addition, many Arab students from wealthy families paid for their own studies in Czechoslovakia, given its good reputation in the region. In 1960, of 2,000 students studying in Czechoslovakia, 760 were foreign (of whom 400 were Arab) (Hannova, 2014, p. 374). In 1961 the Czech government founded the Seventeenth of November University in Prague specifically to cater to students from Arab and African countries, and included courses on Marxism-Leninism. The university was short-lived, however; the significant investment in scholarships and the education of foreign students was expected to bring about Soviet revolutions in their home countries, but growing disillusionment over high costs with little reward meant that the university shut down in 1974 (Hannova, 2014).

Among Western capitalist countries many scholarship programs that were founded during the Cold War still exist as part of broader cultural diplomacy efforts. For example, the Fulbright Program continues to educate students from around the world. It now funds roughly 8,000 students a year, of whom 4,000 are international students pursuing advanced degrees in the United States. Data on the Fulbright Program indicates that between 2005 and 2015 roughly 1,500 students from the Arab world went to study in the United States through two 
programs: the Fulbright Foreign Student Program and the Foreign Language Teaching Assistantship. They came from Algeria, Bahrain, Egypt, Jordan, Kuwait, Morocco, Oman, Palestinian Territories, Qatar, Saudi Arabia, Tunisia, and the UAE. Lebanon and Syria are noteworthy exceptions, their exclusion reflecting geopolitical considerations. In part, the Fulbright Program promotes cross-cultural exchanges with the goal of building relationships between citizens of the region and the United States. The application criteria for Jordanians explains that "applicants should be representative and responsible citizens who can contribute to mutual understanding between the people of the United States and Jordan" (JACEE, 2021). The programs are also part of a broader national development project that seeks to bring knowledge and expertise back to the Arab world. Within the region, Egypt, Jordan, and Morocco all have bilateral commissions to support their Fulbright programs, and in each case these commissions are jointly funded by both governments. Bilateral commissions support sending high-calibre students abroad for foreign graduate training as a way to advance their countries' future economic competitiveness. Accordingly, Fulbright grantees enter the United States on a special visa, which requires them to return to their home country for a period of at least two years.

Similar programs, sponsored by the European Commission, have the explicit goal of promoting intercultural exchange and student and staff mobility. Between 2007 and 2013 the European Commission's Erasmus Mundus program sought to "promote European higher education," improve the career prospects of students, and promote exchange programs between Europe and other regions, including the Arab world. Through a set of competitive grants known as Action 2, the Erasmus Mundus program funded partnerships between universities in Europe and those in non-European Union nations, including the North African nations of Algeria, Libya, Morocco, Egypt, and Tunisia. Another program, called the Battuta program, which stands for "Building Academic Ties towards Universities through Training Activities" and was named for the famed Arab scholar Ibn Battuta, funded 285 students at all levels of higher education to study in nineteen partner universities (eight in Europe and eleven in North Africa). Since 2014, when the Erasmus Mundus program became the Erasmus+ program, European nationals have received funding to study in North Africa through the Al Idrisi II program. In its various iterations the Erasmus Mundus program supports the development of higher education in North Africa "in accordance with the foreign policy objectives of the European Union" (EU, 2016). The foreign policy objectives are clear: supporting higher education for economic development in North Africa will result in less 
migration pressure and stronger trade partners for European countries. These scholarship programs to study in the United States, the United Kingdom, and Europe are part of an older model of international higher education that sought to expand the political influence of funding nations and improve their image abroad.

More recently, a number of Arab Gulf states have launched national scholarship programs for their citizens to study at foreign universities. These programs are framed as meeting the demands of the knowledge economy by building expertise in specific fields. They differ from older models in that they are funded by the Gulf states directly and targeted to their own citizens in the name of skill development, not geopolitical priorities. Table 5.1 provides an overview of national scholarship programs by country, degrees, and subjects funded.

These scholarship programs tend to target specific countries and study programs. For example, Kuwait's scholarship program only permits students to study in the United States. According to the Kuwait Ministry of Higher Education, there are currently over 15,000 Kuwaiti students studying in the United States in thirty-nine approved majors. However, the regulations regarding majors are strict: students can only change majors once and if it will not affect their graduation time. The list of approved majors is specific and dominated by applied sciences. The only disciplinary social sciences on the list are linguistics, psychology, political science, and international relations. The only true humanities subject on the list of approved majors is English, which seems related to strengthening English-language education. Other approved majors include special education and teaching English to speakers of other languages. In terms of the creative arts, approved majors are all applied. While studio art is not approved, architecture, interior design, and graphic design are. Moreover, while the list includes eight different engineering specializations and nine different sub-specializations of business administration, subjects such as history, sociology, anthropology, and philosophy are not approved. Neither is there room for interdisciplinary enquiry or emerging fields such as gender studies, human rights, or global studies.

Student scholarship programs also closely regulate where students can study. Although most programs allow students more options than the Kuwaiti program, which only funds study in the United States, they are often limited to the anglophone world and Europe. Both the UAE and Qatar allow students to pursue degrees in Australia, Canada, the United Kingdom, and other English-speaking countries, as well as in Europe and other Arab nations. The King Abdullah Scholarship Program (KASP) is the only government-funded scholarship program in the Arab 
Table 5.1. Overview of Scholarship Programs in Arab Gulf States

\begin{tabular}{|c|c|c|c|c|}
\hline Country & Scholarship program & Degrees & Subjects of study & Country of study \\
\hline Kuwait & $\begin{array}{l}\text { Ministry of Higher } \\
\text { Education Scholarship }\end{array}$ & Undergraduate & $\begin{array}{l}\text { Architecture, biochemistry, biology, business } \\
\text { administration, chemistry, dentistry, nutrition, } \\
\text { engineering }\end{array}$ & USA \\
\hline UAE & $\begin{array}{l}\text { MOHESR Scholarship } \\
\text { Program }\end{array}$ & & $\begin{array}{l}\text { Business, computer science, economics, } \\
\text { engineering, environment studies, health } \\
\text { sciences, information and computer } \\
\text { technology, law, management, medicine }\end{array}$ & $\begin{array}{l}\text { USA, UK, Canada, Australia, } \\
\text { New Zealand, EU countries, } \\
\text { neighbouring Arab countries }\end{array}$ \\
\hline $\begin{array}{l}\text { Saudi } \\
\text { Arabia }\end{array}$ & $\begin{array}{l}\text { King Abdullah } \\
\text { Scholarship Program }\end{array}$ & $\begin{array}{l}\text { Language training, } \\
\text { bachelor's, master's, } \\
\text { PhD programs }\end{array}$ & $\begin{array}{l}\text { Accounting, business, computer sciences, } \\
\text { dentistry, digital media, e-commerce, } \\
\text { education, engineering, finance, health } \\
\text { sciences, hospitality, insurance, law, linguistics, } \\
\text { marketing, medicine, natural sciences, nursing, } \\
\text { pharmacy, psychology, tourism }\end{array}$ & $\begin{array}{l}\text { Canada, USA, UK, Germany, } \\
\text { Italy, Spain, Holland, } \\
\text { Australia, New Zealand, } \\
\text { France, Japan, Malaysia, } \\
\text { China, India, Singapore, } \\
\text { South Korea }\end{array}$ \\
\hline \multirow[t]{2}{*}{ Qatar } & $\begin{array}{l}\text { Hamad Bin Khalifa Al } \\
\text { Thani Scholarship }\end{array}$ & $\begin{array}{l}\text { Undergraduate, } \\
\text { master's, PhD programs }\end{array}$ & & $\begin{array}{l}\text { Arab region (including } \\
\text { Qatar), Australia, UK, } \\
\text { Europe, USA, Canada }\end{array}$ \\
\hline & $\begin{array}{l}\text { Tamim bin Hamad } \\
\text { Scholarship }\end{array}$ & $\begin{array}{l}\text { Undergraduate, } \\
\text { master's, PhD programs }\end{array}$ & & $\begin{array}{l}\text { Arab region (including } \\
\text { Qatar), Australia, UK, } \\
\text { Europe, USA, Canada }\end{array}$ \\
\hline
\end{tabular}


Gulf that permits students to study in Asian nations. Students in KASP are permitted to study in Japan, Malaysia, China, India, Singapore, and South Korea. That said, in practice, the United States has been the primary destination for Saudi students studying through the program. In addition, in the wake of budget shortfalls, the Saudi government has introduced significant reforms to the KASP to limit overall spending and to use funds more strategically. Starting in 2016, KASP recipients must now study in one of the top fifty academic programs in their field, or at one of the top one hundred universities in the world.

The close regulation of both destinations and degree programs simultaneously reifies Western hegemony in the academic system and implies that certain forms of knowledge are more important or prestigious. The lists of approved programs indicate a rank ordering of knowledges that emphasize technical and applied fields over social science knowledge. This rank ordering of knowledges is reinforced by civil society actors as well. In April 2016, a generous new scholarship program was established to support over 15,000 Arab students from modest backgrounds to study in prestigious universities in the region (Plackett, 2016a). The Abdulla al-Ghurair Foundation for Education, which had an initial budget of USD 1.14 billion over ten years, stated that it would only fund students interested in studying mathematics, science, technology, and engineering. The decision to focus on hard sciences is telling. In an article reported in Al-Fanar, Sari Hanafi, the chair of the American University of Beirut's Sociology Department, stated: "We need to encourage top students to do social sciences ... and that means things like scholarships ... How will we solve the problems of ISIS and authoritarian regimes? ... You need real social sciences to properly study this problem and understand it, in order to do anything about it" (Plackett, 2016a). The scholarship program is one of many signals throughout the higher education system that implies that the social sciences and humanities are less valuable and that those who study history, society, the state, and culture are less worthy of support.

\section{International Students}

In addition to having scholarship programs that send national students abroad, the region is increasingly educating students from all over the world, predominantly as fee-paying international students. Over the past two decades the total number of international students studying in Arab nations has increased significantly. Figure 5.1 shows the total number of international students in various Arab nations between 2000 and 2018, using data from the World Bank, and Figure 5.2 shows the 
relative share of international students in systems throughout the region. The figures make it clear that the number of international students has been increasing, and quite dramatically in some countries. Only Lebanon seems to have experienced a decline in its share of international students.

That said, relative proportions vary significantly. Figure 5.2 shows the proportion of all students in each country that are international. It is clear that the three North African countries - Morocco, Tunisia, and Egypt - have proportionally very few international students ( 2 per cent). In contrast, in both Jordan and Lebanon, international students make up approximately 10-15 per cent of the higher education system. Meanwhile, the Arab Gulf states enrol a very high proportion of international students, with international students making up almost 40 per cent of the Qatari system and 50 per cent of the Emirati higher education system. The tremendous growth in the number of international students in Qatar and the UAE reflects the countries' investments in expanding the number of private higher education institutions and branch campuses.

Among the middle-income countries Jordan has been a clear "winner" in recruiting international students since 2003, particularly since 2010. Over the past few years the Jordanian minister of higher education met with representatives from Saudi Arabia, Kuwait, Bahrain, India, and Russia to encourage students to attend higher education in Jordan. The number of international students studying in the country has increased in both raw and relative terms, which benefits the country in various ways. They pay substantially higher tuition rates, and their presence also enhances the nation's regional educational reputation by signalling Jordan as a desirable hub for education. Badran and Badran (2018) analyse Ministry of Education data and show that, in Jordan, programs for international students are yielding substantial gains and serve to subsidize the cost of public education. For example, at the University of Jordan, they find that tuition fees from international students enrolled in undergraduate programs average USD 19,782 a year and generate roughly USD 30 million for the university.

Private universities in Tunisia and Morocco have also been successful in attracting increasing numbers of foreign students, albeit from very small initial enrolments, so overall international enrolments remain very small in both countries. Many of the international students in North Africa attend private universities and come from francophone sub-Saharan African nations. In 2012 the president and founder of a private institution in Tunisia told me that roughly 5 per cent of the institution's students were international, primarily from francophone countries in sub-Saharan Africa, including the Congo, Mauritania, and Gabon. He 
Figure 5.1. Number of International Students in Higher Education, by Country

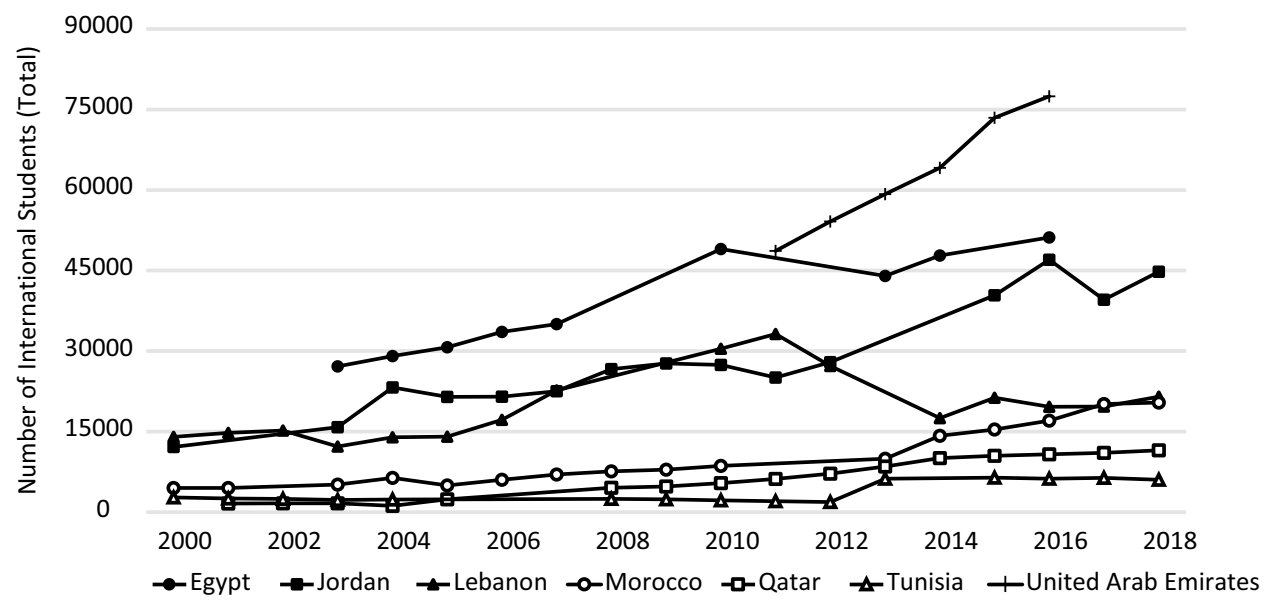

Source: Data accessed through the WB Open Data module for Stata. Indicator UIS. MS.56.T (Azevedo, 2011)

Figure 5.2. International Students (\% Total), by Country and Year

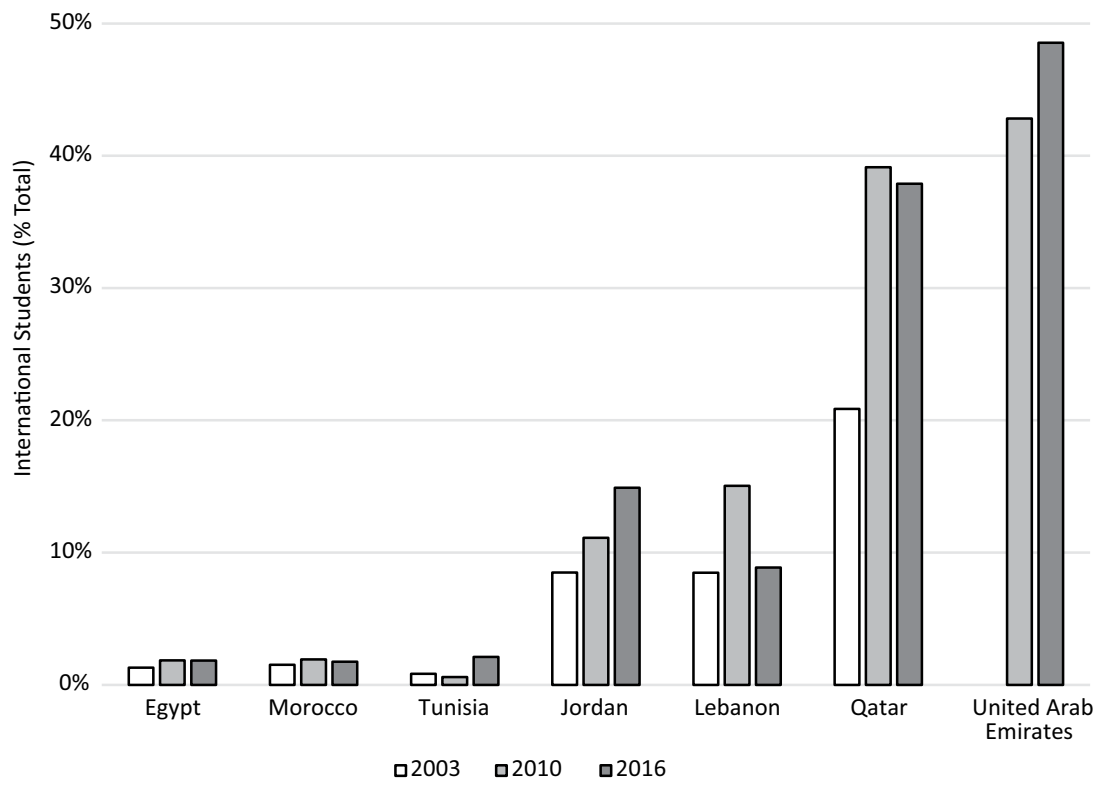

Source: Data accessed through the WB Open Data module for Stata. Indicator UIS.MSEP.56 (Azevedo, 2011)

Note: Data for UAE 2010 comes from 2011 due to missing data in 2010. 
said that its goal was to recruit roughly 10-20 per cent of its students from abroad. In 2017, 12.5 per cent of students in private universities were international, of whom 98 per cent were from sub-Saharan Africa (Sawahel, 2017). Like Jordanian universities, which have strategically placed themselves as a hub for neighbouring Gulf nations, Tunisia's private universities take advantage of their francophone heritage and geographic location to serve students from francophone sub-Saharan African nations.

Table 5.2 shows a regional breakdown of international students' origins, for five countries where data is reliably available. The table points to clear patterns that reflect geographic proximity and linguistic heritage. In Jordan international students overwhelmingly come from other Arab nations. Meanwhile, Morocco and Tunisia are hubs for international students from sub-Saharan Africa, with roughly two-thirds of international students in both countries coming from sub-Saharan Africa. In contrast, the UAE and Qatar attract many students from other parts of the Arab world and South Asia.

The technical literature implies that the more international students a university or nation can attract, the better. Attracting international students is touted as a means to generate revenue, develop students' intercultural competencies, and contribute to mutual understanding. In line with this strategic approach to internationalization, the patterns shown here point to the ways in which countries and institutions are strategically positioning themselves as education destinations for students from particular countries. In 2013, I spoke to the director of recruitment at a private university who said that they were proud that their student body was 50 per cent international, and this fact was advertised on their website. It was not until I probed further that she explained that almost all their international students were from one country, Kuwait. Such a high proportion of students from a single country contrasts discourses in which internationalization is equated with learning from high levels of cross-cultural diversity.

Owing to these trends, many believe that international students are concentrated in low-quality private institutions, allowing entrepreneurs to reap the benefits of students' aspirations for social mobility. In my fieldwork in Tunisia I found that many students, who did not actually know much about private universities, would say off-handedly, "Oh, they are for the [sub-Saharan] Africans" and particularly those from wealthy backgrounds who cannot or choose not to study in Europe but want access to what they characterize as "easy credentials."

Similarly, although the high-profile institutions of Knowledge Village and NYUAD are well known and respected, in the UAE the majority of 
Table 5.2. Origins of International Students (2017, or latest year available)

\begin{tabular}{llcc}
\hline Country & Arab states & Sub-Saharan Africa & $\begin{array}{c}\text { Central, East, } \\
\text { and South Asia }\end{array}$ \\
\hline Jordan & $83 \%$ & $1 \%$ & $9 \%$ \\
Morocco & $19 \%$ & $68 \%$ & $2 \%$ \\
Qatar & $71 \%$ & $3 \%$ & $19 \%$ \\
Tunisia & $32 \%$ & $64 \%$ & $1 \%$ \\
United Arab Emirates & $55 \%$ & $6 \%$ & $31 \%$ \\
\hline
\end{tabular}

Source: UNESCO Institute for Statistics (2019)

Note: Data on international students' origins is either non-existent or not reliable for Lebanon, Syria, and Egypt.

international students are actually studying in private institutions that are located in free trade zones, which are loosely regulated and primarily tuition dependent and revenue generating. Although the UAE specifically developed its private higher education sector to serve its large number of non-citizens, many of whom were born and raised in the UAE but are not eligible to attend public universities, over the past decade there has been a significant and rapid increase in international students as well (KHDA, 2017). In the Gulf states international students constitute a notable source of both revenue and future labour. Recently the UAE extended the length of international student visas, signalling a desire to develop a homegrown pipeline of highly skilled talent for the labour force and reduce dependence on costly recruitment from those educated abroad.

The two outliers in the region are Morocco and Tunisia. Table 5.3 shows the net mobility rate, which is the total number of inbound students minus the total number of outbound students. A negative net mobility rate indicates there are more students travelling abroad than international students incoming. As the table shows, both Morocco and Tunisia have sent thousands more students to study abroad than they bring to their own institutions. The vast majority of Moroccan and Tunisian students are heading to Europe to study in France, Spain, and the United Kingdom, as well as across the Atlantic Ocean to Canada and the United States. The patterns point to a well-known academic hierarchy: subSaharan African students come to North Africa, while North African students head north and west to Europe and beyond to study.

In short, throughout the region the overall number and proportion of international students in higher education systems have been increasing, signalling a high degree of people mobility. While international 
Table 5.3. Net International Mobility in Selected Countries

\begin{tabular}{lc}
\hline Country & Net mobility (2016) \\
\hline Egypt & 19,679 \\
Jordan & 22,431 \\
Lebanon & 3,432 \\
Morocco & $-30,606$ \\
Tunisia & $-14,440$ \\
Qatar & 4,487 \\
United Arab Emirates & 65,745 \\
\hline
\end{tabular}

Source: Data accessed through the WB Open Data module for Stata. Indicator UIS. MENF.56 (Azevedo, 2011)

students often bring diverse experiences and backgrounds that can enrich everyone's learning in and out of the classroom, there is no guarantee that internationalization improves learning. The share of foreign students is a poor proxy for the extent of students' cross-cultural interactions or for other forms of ethnic and economic diversity on university campuses. Indeed, the Arab Gulf states are some of the most diverse societies in the world when one considers the number of nationalities and ethnicities working and living there. Although internationalization may imply the mixing of youth from different national backgrounds, it does not necessarily imply exposure to, or empathy with, those of different class backgrounds. Moreover, the growth of internationalization in the Arab world, as in other parts of the world, ignores uncomfortable realities about the state and citizenship: foreign and national students may be more equal in classroom interactions than they ever will be off campus, as social status in Arab societies maps onto citizenship status in subtle and not so subtle ways.

\section{Provider Mobility}

Although scholarly mobility is as old as the university, it has only been common in the past few decades for whole institutions to move across borders. The movement of higher education programs and providers across national borders, typically in the form of branch campuses or franchise models, is known in the academic literature as cross-border education. The Arab Gulf is arguably the most active region in the world for cross-border higher education. The region's ability to attract high-profile and prestigious Western universities has been celebrated in the media as evidence of an impressive commitment to developing the human resources needed for a future that is 
not dependent on natural resources (Swan, 2013). Of an estimated 311 branch campuses in the world, the UAE alone is home to 41, and Qatar, a nation with only roughly 300,000 citizens, has 11 (C-BERT, 2017). By way of comparison, China, a country with a population of over a billion, has 36 branch campuses. Certainly, not all branch campuses are created equal, and the branch campuses in the Arab Gulf states range from the globally elite NYUAD and Sorbonne University Abu Dhabi to much smaller branch campuses, most of which are for-profit and unregulated.

The first prominent educational hub, Education City, was founded with the stated goal of moving Qatar away from its reliance on oil and gas and to transform it into a knowledge-based economy. As expatriates constitute roughly 95 per cent of the labour force, the country's leaders understood that higher education was crucial to developing a local pool of highly-educated Qataris (Donn \& al-Manthri, 2010; Hvidt, 2015).

Education City currently hosts eleven universities from around the world, including Virginia Commonwealth University, Weill Cornell Medical College, Carnegie Mellon University, Northwestern University, Georgetown University's School of Foreign Service, Texas A\&M University, University College London, and HEC Paris. In addition, the College of the North Atlantic, a community college in Canada, was invited to Qatar to strengthen the vocational education sector. It offers programs in technical fields such as business, engineering, health sciences, and information technology.

Countries choose to host branch campuses for a number of anticipated benefits, including quality and the provision of a specific model of training. Additionally, branch campuses serve as a physical symbol of a country's commitments to global engagement more broadly. They help nations to signal their modernity: "for governments in the GCC, education most certainly has symbolic value in terms of signifying modernity and giving the appearance of the redistribution of wealth through upholding the social contract" (Ridge, 2014, p. 151). Other goals involve some combination of social and economic development, regional and international competitiveness, and prestige.

Nonetheless, branch campuses can be risky ventures for both universities and host countries. Universities may risk their reputations by becoming mired in scandals, watering down the prestige of their academic degree, or by simply failing to attract necessary students and faculty. Indeed, there is no shortage of stories covering scandals and failures of branch campuses. NYUAD has been a focus of criticism by members of its New York-based campus, with workers' rights in the 
UAE being one of the primary areas of contestation. As recently as 2018, the university promised to pay thousands of unpaid guest workers from India, Bangladesh, and Pakistan, and concerns over low levels of faculty engagement at the home campus and a lack of academic freedom in branch campuses have dominated media coverage of NYU's Abu Dhabi and Shanghai campuses.

Branch campuses are not without their detractors within Arab societies as well. The governments of Arab Gulf states have paid substantial sums of money to host Western universities. Many Gulf publics are questioning the value of branch campuses and the government's justification for spending so much money on so few citizens. Qatar initially promised Cornell University USD 750 million over its first decade (2001-11) to establish its medical school in Doha. Since then the Qatar Foundation has continued to provide generous support for Education City. In 2014 it spent roughly USD 320 million on Education City, with Cornell University receiving an estimated USD 121.7 million, Georgetown University USD 59.5 million, and Northwestern University USD 45.3 million for their Doha campuses (N. Anderson, 2015).

Education City remains almost entirely funded by the Qatar Foundation, and there is no indication that this will change soon. In an interview I conducted in Qatar, an employee of the Qatar Foundation explained that the current model encourages the idea that Qatar has purchased its elite universities. "It is based on the capitalist system; it suggests that we have a product [knowledge] and you can pay for it." The implication is that Qatar's relationship with branch campuses is one of economic transaction, rather than equal academic partnership.

One of the major critiques of the branch campus system is that it is educating few local students, therefore raising questions about who benefits from these investments. Local students who enrol in the branch campuses have to meet roughly the same admissions criteria as foreign students do. However, initially, local students' academic abilities in English were weak. One interviewee described this as "challenges with academic standards," stating, "At first, English proficiency was a major issue, but they've worked hard to adapt to that and support students." The percentage of local students admitted to branch campuses in their first few years was quite low. In 2010 the inaugural class of NYUAD had 150 total students, and students from the United States represented about a third of these. Eight years later, according to NYU, the undergraduate class admitted in 2019 was 15 per cent Emirati, and the UAE constituted the largest single nationality (NYUAD, 2019). Meanwhile, in Education City many campuses are now majority Qatari. Virginia Commonwealth University, which focuses on the arts, is 80 per cent 
Qatari; Texas A\&M University is 50 per cent Qatari; and Georgetown School of Foreign Service is $30-40$ per cent Qatari.

These changes have occurred in part because primary and secondary education has responded to families' desire for students to attend branch campuses, and in part because specific government initiatives have created pipelines for talented locals to attend them. In practice, this means that local students tend to come from specific feeder schools that prepare them for an elite university education. In Doha these are primarily Qatar Academy and the American School of Doha, which raises concerns that Education City is essentially a bastion for well-educated Qatari elites. Moreover, there is an enduring scepticism over the qualifications of local students. One alumnus of NYUAD with whom I spoke explained: "The number of Emiratis has been increasing. Some people say it's just an agenda, we have to placate the people funding us, and to an extent, I think that's true."

Even as the percentage of local students has increased, branch campuses are still small players in the overall higher education system. Official statistics report that in 2017-18, 18,628 Qatari citizens were enrolled in the public higher education system, which includes Qatar University and two colleges. Meanwhile, in the same year, only 1,313 Qatari citizens were enrolled in the Education City branch campuses (PSA, 2018). Yet, public institutions, which serve the overwhelming majority, are given less financial support and academic autonomy. In an interview I conducted with a higher education researcher in the region, he exclaimed, "You have Education Village, with private and branch campuses, and you have Qatar University. And there is no relationship between them."

Dr. El Amine, a Lebanese expert of higher education, explained his scepticism of the Arab Gulf states' branch campuses: "They are paying them to be there, and Ahlan wa Sahlan (Welcome)! - please bring your students, bring your professors." He continued: "But, in terms of students, who are the students studying in these universities? In numbers, they are practically nothing, in the hundreds. How can they change higher education? These are just business for the universities in the [United] States. They are paid for, and you can ask everyone, they are paid by the government of the Emirates to show 'We are good, we have good universities coming from outside.' But in fact, those who are studying there, they are not nationals. The professors are foreigners and the students are foreigners. They are taught in foreign languages." Attitudes like this are not uncommon and reflect the deep scepticism over branch campuses in the Arab Gulf states.

Similar scepticism is exhibited when it comes to the involvement of branch campuses in their societies. The programming of community 
engagement is framed as one way in which the university can share its expertise with the local community. It typically includes supporting policy dialogue or convening artistic and cultural events. Observers, however, many within Education City itself, have voiced scepticism over how community engagement is actually being conducted. In a personal interview with a former employee at Georgetown's School of Foreign Service-Qatar (SFS-Q), Kayyali (2016) documented the scepticism. The interviewee said: "The not-so-pretty side of things has been community engagement. Random classes have been offered to ministry employees and civil servants because they are just a box for SFS-Q to tick off and say, 'WE ARE ENGAGING.' However, in my opinion, real engagement can only happen when real transfer of knowledge takes place" (Kayyali, 2016, pp. 36-7). In an interview I conducted, an observer suggested that branch campuses had little impact: "In small countries, like the Emirates and Qatar, it's a matter of self-image to say, 'We have good universities.' But the value of it in terms of social change, social value, social knowledge, I assume, is nothing. Epsilon. Very, very small. 0.0001 , or something like that."

Similarly, a number of critics have pointed out that many of the academics working in Education City may have been recruited for subject-matter expertise, not necessarily because of an interest in Qatar or Qatari society. This can result in mutual distrust or isolation. Kayyali (2016) cites an interview with an employee of the Qatar Foundation who exclaimed: "There are no structural incentives for their American faculty to integrate and learn about the local Qatari culture. There is distrust, distance and isolation of Education City which is problematic to us" (p. 38). In the UAE I spoke with faculty and students at NYUAD who thought that a similar dynamic was playing out there; they said that they did not really interact with Emirati students, who make up an admittedly small proportion of all students. For example, when I asked one student about his experience with Emirati students at NYUAD, he replied: "In general, we don't interact with them. There are very few students who form an actual bond with Emirati students." One faculty member with whom I spoke said, "I don't have any Emirati students I don't know them."

Many of those working in and researching branch campuses, however, largely rejected these criticisms as the growing pains associated with any new initiative. One researcher with whom I spoke in Qatar explained: "Yes, there were some challenges at first, but over time these get worked out. The model of co-ed education is working - students work together. There may have to be some accommodation, like a female-only lounge, but these are small changes." 
With branch campuses in Doha celebrating their fifteenth year and NYUAD nearing its tenth year, there is no doubt that these ambitious projects have had an impact. In 2019 I spoke with a researcher who had watched Education City change. He explained: "The scene is changing. It has changed dramatically over the past fifteen years." Those working within the Qatar Foundation ecosystem consistently pointed out the impact that Education City had on diversifying the higher education landscape, particularly for females, as some families chose not to send their daughters abroad. A professor who works at one of the campuses in Education City discussed the project's role in addressing female education: "Face it, it's cheaper to send a thousand Qataris abroad than to set up these campuses, but they did it." She explained that part of the narrative about Education City and its founding is that "Qatari women can't go abroad" and are "a segment of the population that isn't being attended to, and so this addresses a local need ... As a project, it's some politics and some social engineering." One young Qatari male with whom I spoke, a graduate of Georgetown's School of Foreign Service, also based his understanding in terms of need, stating, "It's just what was needed."

Neha Vora's (2018) ethnography of teaching and learning at Texas A\&M University at Qatar, an American branch campus in Doha, offers a more nuanced view of daily life in branch campuses than is typical in the media. Vora describes how students in her Anthropology 101 course took offence at a core text that portrayed marriage between cousins as exotic, and she reflects on how teaching in Doha helped her understand the extent to which anthropology as a discipline, and American higher education as an enterprise more broadly, continue to rely on orientalist tropes and to centre Western students' perspectives. She suggests that the ethnic, national, and linguistic diversity, close interactions with faculty, and campus resources available to her Doha students create opportunities for learning that are out of reach for students on American campuses. Her book is an ardent call for greater humility among Western scholars who assume that the role of foreign campuses is to "open the minds" of students in the region.

Branch campuses clearly defy oversimplification. They have been highly debated in both the local and the international media and criticized as ostentatious and controversial. At the same time, Arab Gulf states have invested heavily in them and seem to have found a fast track to elite knowledge production and human capital training in the name of improving higher education quality, scientific research, and human development across the region. One reason branch campuses may garner such resistance is that they threaten the traditional hierarchies. The 
model of the elite branch campus unsettles historic models of internationalization based on sending Arab students to study in the West to obtain academic knowledge and then return to their home countries. Instead, they establish Arab nations as home to elite centres of learning. At the regional level the Arab Gulf states are upending traditional regional hierarchies where older American universities - the American University of Beirut and the American University in Cairo - and national universities such as Cairo University were considered the best institutions and attracted international students from across the region. At the same time, admission into NYUAD is more competitive than admission to its New York campus. It seems that the nouveau elite status of higher education in the nouveau riche Arab Gulf states is most controversial among those who feel that their status is threatened, Western institutions included.

While the elite branch campuses of the Arab Gulf are the most high-profile new universities in the region, other institutions offer distinctive models of what international co-operation could look like. One of the oldest models of foreign co-operation in the Arab world is found in the Middle Atlas Mountains of Morocco where, in 1995, al-Akhawayn University (which means "the two brothers" in Arabic) was established by King Hassan II of Morocco and Crown Prince Abdallah bin Abdel-Aziz of Saudi Arabia as a symbol of mutual respect and partnership. It was founded with the distinctive aim of creating an American-style liberal arts university in North Africa. The university was unlike any other in Morocco - a public, but privately governed, tuition-charging, liberal arts university that has a residential campus and teaches in English, not Arabic or French. Although the university charges tuition, it is officially a public institution and has received government support since its beginnings. Al-Akhawayn has retained an elite character, in part because its tuition fees are high for most Moroccan families and in part because it teaches in English and has competitive admissions, accepting roughly a third of all applicants. Its elite character is also bolstered by the fact that members of the royal family have attended the university. Al-Akhawayn represents a unique model in the region as a symbol of elite liberal arts education that is based on regional co-operation between Saudi Arabia and Morocco and that predates the creation of the Western branch campuses in the Gulf. As a Sunni monarchy whose king enjoys tremendous legitimacy from his long lineage, Morocco has a history of building alliances with Gulf monarchies, which has included funding for infrastructure and social welfare programs. More recently, Morocco's Mohammed V University, a public university, opened a branch campus in Doha. 
Another model that has spread throughout the Arab world is the joint or binational university, which has been championed by Germany. In the 2000s the German Academic Exchange Service (DAAD), a semigovernmental organization, helped establish new universities in both Jordan and Egypt based on the German model. The new universities teach German-language courses and promote study in Germany. In 2002 the German University of Cairo was founded by presidential decree as a private university. At the time it was the first German university outside Germany. Following its success, the German Jordanian University (GJU) was founded in 2005 as a new model of public university, in close partnership with the German government and funded for its first four years by DAAD. After two years of studying at the GJU, students can complete their degree program in Germany.

In 2013 I visited the GJU, which is located on the outskirts of Amman but has convenient public bus service from the capital. The contrast between it and the University of Jordan, as a large public university in Amman, is noticeable. Course lectures were officially conducted in English, but students roaming the campus spoke in colloquial Jordanian Arabic, accompanied by code switching between the two around campus. Students wore tight jeans, boots, bright colours, and expensive jewellery and accessories. Very few of the women were veiled, and almost none was wearing the long trench coat common in public universities. I watched mixed-gender groups of girls and boys hanging out together, chatting with one another, as well as girls and boys coupled together who were talking alone - signals of intimacy and mixedgender interactions that were much less visible at my visits to public universities. It was immediately clear that GJU intentionally attracted a distinctive student body, one that was multilingual, urban, uppermiddle class, and Westernized.

The GJU is a high-profile project for the governments of Germany and Jordan. It is a partnership that seeks both to improve the quality of technical education in Jordan and to strengthen links between Germany and Jordan. An employee of DAAD responsible for student recruitment explained to me that the GJU was considered "the crown jewel" of DAAD projects in the Middle East and North Africa region. For Germany, it is a vie for soft power that will expand its influence in the region. Walking the hallways of the university, I could not help but think that it was highly successful. I saw students wearing clothes that bore the German flag, and posters about future options for studying in Germany. For Jordanians, enrolment at the GJU offers a perfect combination of foreign credentials, which are viewed as superior in the local labour market, and a possible pathway to emigrating to Europe. 


\section{Internationalization as a National Project}

Throughout the region Arab families, universities, and governments have embraced higher education's global mandate. This chapter argues that at the individual and institutional level internationalization signals legitimacy and distinction (Waldow, 2018). As the contrast between the region's middle-income countries and the wealthy Arab Gulf states makes clear, however, internationalization varies across the Arab world. In the region's middle-income countries internationalization tends to be resource generating. Discourses of system strengthening are linked to the idea of individual opportunity by framing internationalization as a way to cultivate opportunities for mobility and migration for a globally oriented middle class. Among upper-middle-class families, foreign-language degree programs and opportunities for student or scholarly mobility are celebrated as a form of expanded opportunity. Their primary benefit is to confer status on participating individuals. In the aggregate they constitute a class project of the globally oriented upper-middle class by supporting their aspirations for transnational mobility and status. Around the world it is those with strong English-language skills, financial resources, and cultural capital that have always been most likely to benefit from internationalization, and the Arab world is no different in this regard.

Internationalization as a class project is useful for Arab governments that are seeking to satisfy the demand of upper-middle-class families, while also signalling to other nations their willingness and ability to participate in a global knowledge economy. For the middle-income nations of the region, internationalization helps garner external resources. Scholarship programs (such as the bilateral Fulbright commissions) and new joint initiatives (such as the GJU) are jointly funded, allowing Arab governments to signal their own investment in their citizens and their ability to garner additional funding from other donors or governments. Contestation over such projects is rare, in part because they serve primarily privileged nationals.

In the Arab Gulf states internationalization tends to be resource intensive and is mapped onto a broader state project of modernization and strategic nationalization of the labour force. In the Arab Gulf internationalization raises basic questions about the role of higher education in nation-building. Romani (2009) argues that "it is highly unlikely that the influx of new higher education venues can proceed without engaging the conflict between nationalism and the necessary internationalism of the projects" (p. 5). The importation of international branch campuses in the Arab Gulf states has largely been interpreted, 
particularly in the West, as "copying" external models and even "importing" the prestige that is associated with elite universities in the United States (Wilkins \& Huisman, 2012).

This dominant model of internationalization reifies Western influence and colonial and imperial hierarchies, including a global linguistic hierarchy. For universities, internationalization often entails not only offering foreign-language programs but also teaching in foreign languages, typically English or French. Increasingly, English is characterized as the only truly global language. As a result, "national academic systems enthusiastically welcome English as a contributor to internationalizing, competing, and becoming 'world class'" (Altbach, 2013, p. 2). In the Arab world, language of instruction maps onto status hierarchies between universities. The most elite universities throughout the region teach in English. Other European languages, including French in former French colonies and German in the German universities in Egypt and Jordan, are also promoted as languages of socio-economic power and promise future opportunities for mobility. In contrast, university programs that use Arabic as a language of instruction are characterized as trapping students in local labour markets or limiting them to outdated sources of knowledge.

Beyond language, current approaches to internationalization reinforce the idea that by adopting Western models of higher education, Arab states will secure the external legitimacy associated with high-quality higher education. This Western orientation of many internationalization projects may undermine faith in local capacity and ignore alternative visions of quality. An alternative approach to internationalization in the region would disrupt the assumed linkages between "international," "Western," and "prestige." This might start by recognizing that the Arab world is already deeply internationalized: its youth are already multicultural, multilingual, cosmopolitan, and mobile. International engagements are an opportunity to highlight the region's cultural heritage and to share the region's knowledge with a world that is, at best, ignorant and, at worst, overtly biased in its perceptions of the Arab world. Another approach is to strengthen regional collaboration: stronger links between the region's institutions could build opportunities for regional collaboration to tackle similar social issues and promote knowledge production in Arabic. 